\title{
INVESTIGATION OF THE LIGHTNING ACCIDENT WHICH INVOLVED 30 COWS
}

\author{
N. Kitagawa ${ }^{(1)}, M$, Ohashi $^{(2)}$, and T. Ishikawa ${ }^{(3)}$
}

(1) Central Lightning Protection Inc., [home address] 422-16 Okubo-Ryoke, Saitama-shi, 338-0826 Japan

(2) Tokyo Denryoku Co., [home address] 1-31-12 Saiwaichyo, Fuchyu-shi, Tokyo, 183-0054 Japan

${ }^{(3)}$ National Defense Medical College, [home address] 6-22-8 Sakuradai, Nerima-ku, Tokyo, 176-0002 Japan

\begin{abstract}
This paper investigates the lightning accident in 1999 which killed 19 cows out of 30. The cows were kept in a farm where several high larch trees grew, and during the active thunderstorm, the 19 cows gathered closely around one of the trees which was struck by lightning. It is presumed that the lightning current, once reached the tree, flowed into the nearest cows and spread into other touching cows, finally flowing into the ground through the cows situated outer side of the group. As opposed to the step voltage effect, this account of the current flow is particularly supported by the unique habit of cows that they gather closely, touching each other when they are frightened. The paper concludes by proposing some safety methods for cattle against lightning hazards.
\end{abstract}

Keywords: cattle, death by lightning, ground flash

\section{Introduction}

Golde and Lee (1976) state in their review article "Death by Lightning" that the step voltage is not fatal for human beings but it likely causes death for quadrupeds. The article carries the photograph of 22 cows which were killed as a result of a lightning strike to a tree. Generally, however, the lightning injuries of cattle and wild animals have not been well disclosed.

The authors had a chance to investigate the lightning accident which killed 19 cows out of 30. Shortly after the lightning strike, the authors investigated the state of the cows, trees and ground surface. The 19 dead cows lay down touching closely each other around the tree which was struck by lightning.

\section{The thunderstorm and the damages of the lightning strike}

The accident occurred on August 7, 1999 about 04:00 JST at a cattle farm in Hokkaido. Thirty cows were kept in the farm where several high larch trees grew. Active thunderstorms begun about 03:00 JST and a ground flash struck one of larch trees about 04:00 JST. Eighteen cows were found dead, lying and touching closely each other around the struck tree. One cow

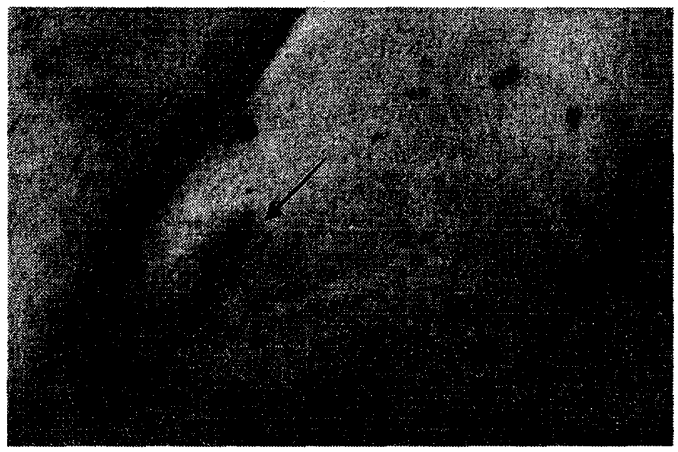

Fig.1. Keronographic mark on the breast 
that was half a meter apart from the group had been found alive, and was treated, but died about half an hour later. One cow which directly touched the struck tree, was found to have been put with keraunographic mark on its breast. Fig.1. shows the photograph of the breast. The other cows that stayed far apart from the gathering group were not injured.

The ground surface was wet and partly covered by puddles. The positions of the dead cows and struck tree are illustrated in Fig.2. Two long traces of peeled bark were found on the trunk of the struck tree. The traces ended at the height of about $1 \mathrm{~m}$ from the ground.

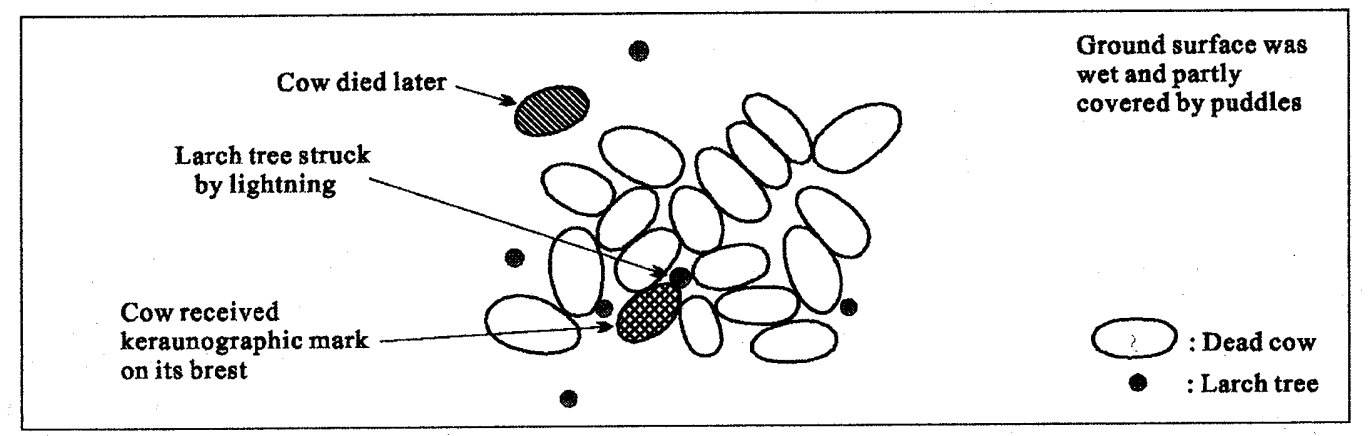

Fig.2. Positions of 19 dead cows

\section{Deduction of the way of lightning current flow}

It is assumed that the death of cows was caused not by the step voltages but by the current flowed directly from the struck tree. The lightning current initially reached the tree, flowed into the nearest cows, flowed into other adjacent cows, penetrating all the gathering cows, and finally flowed into the ground through the cows which were situated outer side of the group. It is inferred that the cow died later had received a side flash from the nearest cow.

Cows have a unique habit to gather closely, when they are frightened. In the present accident, the elder and stronger cows gathered closely around the struck tree and were killed by lightning current. The younger cows that could not enter the gathering group were not injured.

The feature of the photograph shown in the article by Golde and Lee is very similar to those of the present accident and it is highly probable that the cows were killed by the similar current flow.

\section{Concluding remarks}

It is difficult to draw a definite conclusion from the investigation of a single case. However, considering the unique habit of cows to gather closely when they are frightened, the occurrence probability of a lightning accident that kills all gathering cows by the direct current flow seems to be high.

Therefore, as the safety methods for cattle against lightning hazards, the authors propose the following:

"The best way is to keep cattle in a cattle shed. It is preferable to equip a lightning conductor system to the cattle shed. In case a shed is not available, the second-best way is to keep cattle within a farm region where no high trees grow."

\section{References}

Golde R.H. and W.A. Lee, Death by lightning, Proc. IEE. 123, 1163-1180, 1976.

(Received December 21, 2001; revised December 27, 2001; accepted January 24, 2002) 